\title{
EKSPLORASI KONSORSIUM MIKROB FILOSFER DAN RIZOSFER ASAL BERBAGAI EKOSISTEM DI KABUPATEN SIGI PROVINSI SULAWESI TENGAH
}

\section{EXPLORATION OF MICROB CONSORTIUM PHYLLOSPHERE AND RHIZOSPHERE OF ECOSYSTEMS IN SIGI DISTRICT CENTRAL SULAWESI PROVINCE}

\author{
Aris Aksarah Pas ${ }^{1 *}$, Didy Sopandie ${ }^{2}$, Trikoesoemaningtyas², Dwi Andreas Santosa² \\ ${ }^{1}$ Program Studi Agroteknologi, Fakultas Pertanian, Universitas Alkhairaat, Jl. Diponegoro, Fakultas \\ Pertanian Universitas Alkhairaat, Palu 94221, Indonesia \\ ${ }^{2}$ Program Studi Agronomi dan Hortikultura Fakultas Pertanian IPB, Bogor
}

\begin{abstract}
ABSTRAK
Eksplorasi konsorsium mikrob pada suatu ekosistem merupakan serangkaian kegiatan yang bertujuan memperoleh mikrob yang hidup dalam konsorsium dan bermanfaat bagi pertumbuhan tanaman. Penelitian bertujuan untuk memperoleh sampel daun dan tanah pada berbagai tumbuhan dalam suatu ekosistem, sebagai sumber konsorsium mikrob filosfer dan rizosfer untuk diuji efektivitasnya meningkatkan pertumbuhan dan hasil tanaman padi. Metode penentuan lokasi berdasarkan metode Transek Sampling/Line Intersep Plot Design pada wilayah seluas $5196.02 \mathrm{~km}^{2}$. Penentuan letak lokasi berdasarkan penarikan contoh bertujuan (Purposive sampling) meliputi ekosistem : sawah, kebun, padang rumput dan hutan. Hasil penelitian menunjukkan bahwa, Kabupaten Sigi memiliki keanekaragaman hayati pada berbagai ekosistem yang berpotensi sebagai sumber konsorsium mikrob filosfer dan rizosfer. Dari hasil ekplorasi diperoleh sampel sebanyak 48 jenis tumbuhan yang terdiri atas tumbuhan tingkat bawah 30 jenis, tingkat tiang 12 jenis dan tingkat pancang 6 jenis. Hasil isolasi sampel daun dan tanah diperoleh 144 konsorsium mikrob filosfer dan 48 konsorsium mikrob rizosfer.Konsorsium yang diperoleh kemudian diuji efektivitasnya terhadap pertumbuhan dan hasil tanaman padi pada tahap penelitian selanjutnya.
\end{abstract}

Katakunci: sampel, purposive sampling, isolasi, plot

\section{ABSTRACT}

Microbial consortium exploration in an ecosystem is a series of activities aimed at obtaining microb living in a consortium and beneficial to plant growth.The study aimed to obtain leaf and soil samples in various plants within an ecosystem, as a source of a consortium of microbial phyllosphere and rhizosphere to be tested for their effectiveness in increasing the growth and yield of rice crops. The method of determining the location is based on the method of transect sampling/line intersep plot design on an area of 5,196.02 $\mathrm{km}^{2}$. Site determination based on purposive sampling includes ecosystems: rice fields, gardens, pastures and forests.The results showed that, Sigi District has biodiversity in various ecosystems that have potential as source of consortium of microbial phyllosphere and rhizosphere. From the exploration results obtained a sample of 48 species of plants consisting of plants under the level of 30 species, 12 pile poles and 6 types of stakes. The results of the isolation of leaf and soil samples obtained 144 consortium of microbial phyllosphere and 48 consortium of microbial rhizosphere. The obtained consortium was then tested for its effectiveness on the growth and yield of rice crops in the next stage of the study.

Keywords: sample, purposive sampling, isolation, plot 
Jurnal Ogrotech 8 (1) 8-17

\section{Pendahuluan}

Eksplorasi konsorsium mikrob merupakan serangkaian kegiatan yang bertujuan memperoleh sumber mikrob dalam bentuk konsorsium. Mikrob dapat diperoleh pada suatu ekosistem dan dapat dimanfaatkan untuk meningkatkan pertumbuhan tanaman. Pemanfaatan mikrob dalam bentuk konsorsium sebagai pupuk hayati, merupakan upaya mengurangi penggunaan pupuk sintetik secara terus menerus. Mikrob hasil eksplorasi dari berbagai ekosistem yang kaya akan keanekaragaman hayati, memiliki potensi mikrob yang mampu menambat $\mathrm{N}_{2}$, melarutkan $\mathrm{P}$ dan menghasilkan hormon tumbuh tanaman, atau senyawa antagonis.

Sturz dan Nowak (2000) menyatakan bahwa, dalam mengeksplorasi mikrob perlu suatu strategi, yang dimulai dari kultivasi dan purifikasi mikrob yang bersifat menguntungkan. Tahap selanjutnya adalah menguji kemampuannya dalam meningkatkan pertumbuhan tanaman dan mengaplikasikan pada tanaman sedini mungkin agar populasi mikrob mendominasi pada jaringan tanaman yang diinokulasikan. Eksplorasi mikrob potensial yang berperan dalam pertumbuhan tanaman masih terus dikembangkan sebagai kajian ekologi, fisiologi dan interaksinya dengan tanaman. Kegiatan tersebut merupakan upaya untuk mendukung pertanian yang berkelanjutan.

Eksplorasi dilakukan dari sumber dan lokasi yang lebih variatif, termasuk dari gulma dan tumbuhan yang hidup liar. Kebanyakan spesies mikrob dipengaruhi oleh biologi tanaman dan lingkungannya (Morris 2001). Faktor lingkungan berpengaruh terhadap keberadaan mikrob (Freiberg 1998). Beberapa faktor lingkungan seperti tipe tanah, kelembaban tanah, $\mathrm{pH}$ dan suhu, serta umur dan kondisi tanaman mempengaruhi efek rizosfer (Rao 1995; Reisberg et al. 2013). Pati (1992) melaporkan bahwa pada daerah tropis dengan ketersediaan hara rendah dalam tanah, bakteri penghuni permukaan daun sangat memperkaya status hara tanaman melalui penambatan $\mathrm{N}_{2}$ dari atmosfer. Rao (1982) menyatakan bahwa tanaman padi berpotensi dikembangkan melalui pemanfaatan mikrob berdasarkan penelitian IRRI (International Rice Research Institute).

\footnotetext{
${ }^{*}$ Penulis Korespondensi

E-mail: arisaksarahpas@gmail.com

Telp: +62-81341012887
}

e-ISSN : 2621-7236

p-ISSN : 1858-134X

Berbagai ekosistem yang dapat ditemukan di Kabupaten Sigi memiliki keanekaragaman hayati, antara lain : hutan, padang rumput, sawah dan kebun. Ekosistem tersebut terletak pada koordinat $0^{\circ} 52^{\prime}-2^{\circ} 03^{\prime}$ Lintang Selatan dan $119^{\circ} 38^{\prime}-120^{\circ} 21^{\prime}$ Bujur Timur, berada tepat pada garis khatulistiwa menjadikan wilayah ini memiliki suhu udara yang cukup panas (BPS 2010).

Penelitian ini bertujuan untuk melakukan eksplorasi konsorsium mikrob filosfer dan rizosfer, berupa sampel daun dan tanah pada berbagai tumbuhan dalam ekosistem di Kabupaten Sigi Provinsi Sulawesi Tengah, untuk diuji efektivitasnya dalam meningkatkan pertumbuhan dan hasil tanaman padi.

\section{Metode Penelitian}

\section{Tempat dan waktu}

Pelaksanaan penelitian dimulai bulan Juli hingga Oktober 2012. Pengambilan sampel dilakukan pada ekosistem di Kabupaten Sigi Provinsi Sulawesi Tengah. Identifikasi tanaman dilakukan di UPT Herbarium Celebense Universitas Tadulako (Untad) Palu. Percobaan kultivasi mikrob dilaksanakan di Laboratorium Bioteknologi Tanah, Departemen Ilmu Tanah dan Sumberdaya Lahan, Fakultas Pertanian IPB Bogor.

\section{Bahan dan alat}

Bahan yang digunakan terdiri atas : bahan eksplorasi, sampel daun dan tanah, bahan untuk kultivasi dan bahan untuk media biakan. Alat yang digunakan terdiri atas : alat untuk eksplorasi dan alat untuk media biakan.

Metode

Survei lokasi

Penentuan lokasi berdasarkan metode

Transek Sampling/Line Intersep Plot Design (Fachrul 2007) pada wilayah seluas 5.196,02 $\mathrm{km}^{2}$. Jarak antar titik $10 \mathrm{~km}$, jarak dari jalur 200 $\mathrm{m}$, luas petak 0.65 ha persegi. Penentuan letak lokasi berdasarkan penarikan contoh bertujuan (Purposive sampling), meliputi ekosistem : Sawah, kebun, padang rumput dan hutan.

Pengambilan sampel

Pengambilan sampel berdasarkan metode penarikan contoh otoritas (Steel \& Torrie 1980), dengan ketentuan sebagai berikut:

1. Sampel daun dan tanah yang diambil dari tanaman yang tumbuh khas dan dominan dibanding tanaman di sekitarnya. Lokasi 


\section{Jurnal Agrotech 8 (1) 8-17}

pengambilan sampel dilengkapi dengan data ketinggian tempat dan $\mathrm{pH}$ tanah.

2. Tanaman sampel belum tersentuh perlakuan teknik budidaya.

3. Pemilihan sampel dititik lokasi berdasarkan metode diagonal, tanaman yang paling sering muncul dipilih sebagai sampel.

4. Tanaman yang diambil dari vegetasi dapat meliputi 3 tingkat, yaitu :

- Bawah : tinggi tanaman hingga $1,5 \mathrm{~m}$ (rumput, perdu dan semak).

- Pancang : tinggi tanaman lebih tinggi dari 1,5 m sampai pohon muda berdiameter kurang dari $10 \mathrm{~cm}$.

- Tiang : berdiamater lebih dari $10 \mathrm{~cm}$.

5. Daun tanaman yang diambil dari ranting/cabang yang sama dan dikenai sinar matahari langsung (menghadap ke Timur), dengan kriteria :

- Daun muda (daun ke-2)

- Daun sedang (daun ke-3)

- Daun tua (daun ke-4) (Kinkel 1997)

6. Tanah yang diambil adalah tanah pada akar tumbuhan yang melekat pada perakarannya. Beberapa helai cabang akar dipotong kemudian diambil tanah rizosfernya yaitu tanah yang melekat pada rambut-rambut akar atau yang berjarak kurang dari $1 \mathrm{~mm}$ dari permukaan rambut akar. Tanah rizosfer tersebut dikikis dengan menggunakan spatula steril dan disimpan dalam kantong plastik yang telah diberi label sesuai lokasi titik pengambilan sampel.

Daun dan tanah yang diambil dipisahkan, dibungkus dengan dengan kantong plastik dalam wadah terpisah, diberi label dan disimpan dalam cooler box yang berisi es. Sampel disimpan pada suhu $4{ }^{\circ} \mathrm{C}$ hingga pengerjaan dilaksanakan di laboratorium (Gofar 2003).

Kultivasi mikrob dari sampel

1. Sampel daun

a. Masing-masing contoh daun dipotong melintang dengan lebar $3 \mathrm{~mm}$ dan tiap potongan mengandung tulang daun dan antar tulang daun (Bills 1996).

b. Lalu diambil secara acak masing-masing $1 \mathrm{~g}$ potongan dari setiap kelompok umur daun. Mikrob yang diperoleh terdiri atas mikrob epifit dan endofit

c. Prosedur kultivasi konsorsium mikrob daun epifit dan endofit sebagai berikut :

- Konsorsium mikrob daun epifit dilakukan dengan cara $1 \mathrm{~g}$ daun disuspensikan ke dalam erlenmeyer berisi $10 \mathrm{ml} \quad 0.02 \mathrm{M} \quad \mathrm{KH}_{2} \mathrm{PO}_{4}$.
e-ISSN : 2621-7236

p-ISSN : 1858-134X

Erlenmeyer berisi sampel dikocok menggunakan rotary shaker dengan kecepatan $150 \mathrm{rpm}$ selama 30 menit.

- Konsorsium mikrob daun endofit dilakukan dengan metode yang dikembangkan oleh Suto (2001). Permukaan potongan daun sebanyak $1 \mathrm{~g}$ yang telah diambil mikrob epifitnya, dicuci dengan air mengalir selama 10 menit, disterilkan permukaannya dengan cara potongan daun tersebut direndam dalam etanol $75 \%$ selama 1 menit, lalu digerus dan ditambahkan $10 \mathrm{ml} 0.02 \mathrm{KH}_{2} \mathrm{PO}_{4}, \mathrm{pH}$ 7.2 dalam erlenmeyer. Ekstrak jaringan daun tersebut merupakan sumber mikrob endofit. Erlenmeyer berisi sampel dikocok menggunakan rotary shaker dengan kecepatan 150 rpm selama 30 menit.

- Suspensi mikrob daun epifit dan ekstrak daun endofit masing-masing sebanyak $0.5 \mathrm{ml}$ bersama-sama ditumbuhkan dalam $50 \mathrm{ml}$ medium cair laurell $(0.5 \mathrm{~g} \mathrm{NaCl}, 1 \mathrm{~g}$ triptopan pepton, $0.5 \mathrm{~g}$ ekstrak ragi, dilarutkan dalam 1 liter aquades), yang telah disterilkan dengan autoklaf selama 15 menit pada suhu $121{ }^{\circ} \mathrm{C}$ pada tekanan 1 atmosfer.

d. Suspensi dikocok dengan mesin kocok dengan kecepatan $112 \mathrm{rpm}$ selama 72 jam untuk menumbuhkan mikrob.

2. Sampel tanah

a. Sampel tanah ditimbang $10 \mathrm{~g}$ digerus dengan mortar dicampur dengan larutan fisiologis $90 \mathrm{ml}$ steril $(8.5 \mathrm{~g} / \mathrm{l} \mathrm{NaCl}+11$ aquades) dalam erlenmeyer $250 \mathrm{ml}$ yang telah disterilisasi pada suhu $121{ }^{\circ} \mathrm{C}$ selama 15 menit. Erlenmeyer berisi sampel dikocok menggunakan rotary shaker dengan kecepatan $150 \mathrm{rpm}$ selama 30 menit.

b. Larutan NB (8g/l + aquades) dicampur lalu diaduk dengan Magnetic Strirer. Larutan dimasukkan ke dalam erlenmeyer/botol kultur $50 \mathrm{ml}$ dan disterilisasi pada suhu $121{ }^{\circ} \mathrm{C}$ selama 15 menit.

c. Larutan dipipet $1 \mathrm{ml}$ dan dimasukkan ke dalam $30 \mathrm{ml}$ larutan NB (Nutrient Broth) steril, lalu dikocok selama $\pm 3-4$ hari. Pertumbuhan mikrob ditandai dengan terjadinya kekeruhan pada NB (Saraswati et al. 2007). 


\section{Jurnal Agrotech 8 (1) 8-17}

Masing-masing konsorsium disimpan pada media gliserol dalam tabung (ependorf) sebagai master dan pada botol sebagai kultur kerja.

\section{Hasil dan Pembahasan}

Gambaran umum ekosistem Kabupaten Sigi Provinsi Sulawesi Tengah

Kabupaten Sigi Provinsi Sulawesi Tengah terdiri atas 15 kecamatan. Sebelah Utara berbatasan dengan Kabupaten Donggala dan Kota Palu. Sebelah Selatan berbatasan dengan Kabupaten Luwu Utara (Provinsi Sulawesi Selatan). Sebelah Barat berbatasan dengan Kabupaten Mamuju Utara (Provinsi Sulawesi Barat) dan Kabupaten Donggala. Sebelah Timur berbatasan dengan Kabupaten Poso dan Kabupaten Parigi Moutong.

\section{Pengambilan sampel}

Kabupaten Sigi memiliki dua musim, sebagaimana dengan daerah-daerah lain di Indonesia, yaitu musim panas dan musim hujan. Musim panas terjadi antara bulan April September, sedangkan musim hujan terjadi pada bulan Oktober - Maret. Suhu udara rata rata tertinggi terjadi pada bulan Pebruari $\left(27.1^{\circ} \mathrm{C}\right)$ dan suhu udara terendah terjadi pada bulan Agustus $\left(25.7^{\circ} \mathrm{C}\right)$. Kelembaban udara berkisar antara $75-83$ persen. Kelembaban udara ratarata tertinggi terjadi pada bulan Agustus yang mencapai 83 persen, sedangkan kelembaban udara rata-rata terendah terjadi pada bulan Pebruari yaitu 75 persen (BPS 2010).

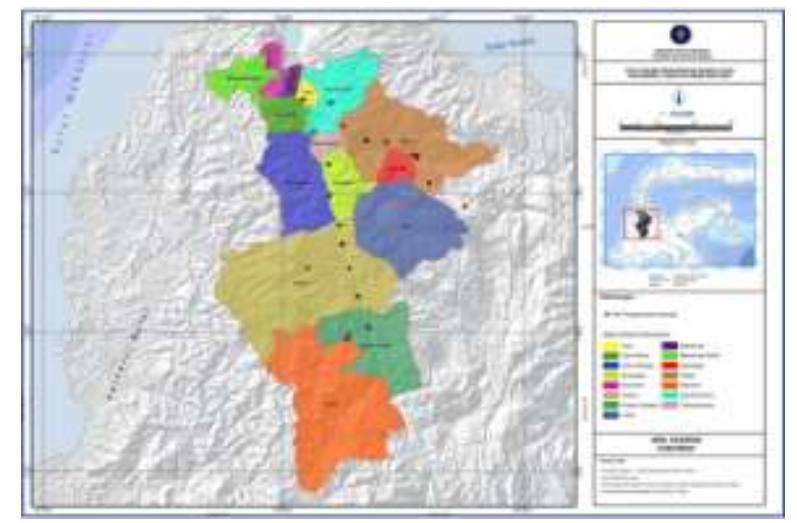

Gambar 1.

Peta titik lokasi pengambilan sampel. Perbedaan warna peta menunjukkan batas wilayah administrasi kecamatan

Pengambilan sampel daun dan tanah dilaksanakan pada $9-16$ Oktober 2012. Penentuan lokasi berdasarkan dua jalur, yaitu
e-ISSN : 2621-7236

p-ISSN : 1858-134X

jalur pertama adalah Palu - Gimpu $( \pm 100 \mathrm{~km})$ sebanyak 10 titik dan jalur kedua adalah PaluPalolo $( \pm 70 \mathrm{~km})$ sebanyak 7 titik. Masing masing titik terdiri dari dua petak sampel (kiri kanan jalur). Setiap petak sampel bisa lebih dari satu ekosistem asal. Titik nol jalur pertama adalah Desa Kalukubula Kecamatan Dolo pada ketinggian tempat $34 \mathrm{~m}$ dpl, sedangkan titik nol jalur kedua adalah Desa Lolu Kecamatan Biromaru pada ketinggian tempat $65 \mathrm{~m} \mathrm{dpl}$. Lokasi tempat pengambilan contoh daun dan tanah berbagai tumbuhan yang spesifik (dominan) berupa ekosistem sawah, kebun, padang rumput dan hutan. Jenis tumbuhan bervariasi mulai dari jenis rumput, perdu dan pohon. Berbagai jenis daun tumbuhan dibedakan berdasarkan daun muda, sedang dan tua mewakili sumber konsorsium mikrob filosfer dan sampel tanah sebagai sumber konsorsium mikrob rizosfer. Peta titik lokasi pengambilan sampel disajikan pada Gambar 1.

\section{Hasil eksplorasi}

Hasil ekplorasi diperoleh 48 jenis tumbuhan sebagai sumber konsorsium mikrob filosfer dan rizosfer. Adapun jenis tumbuhan berdasarkan hasil identifikasi dan dikelompokkan berdasarkan tingkat vegetasi, yaitu :

Vegetasi tingkat bawah:

1. Lantana camara L. (berbentuk perdu berasal dari ekosistem kebun di Desa Tulo Kecamatan Dolo, pada ketinggian $44 \mathrm{~m}$ dpl dengan $\mathrm{pH}$ tanah 6.9).

2. Ageratum conyzoides L. (berbentuk herba semusim berasal dari ekosistem sawah di Desa Tulo Kecamatan Dolo, pada ketinggian $44 \mathrm{~m}$ dpl dengan $\mathrm{pH}$ tanah 6.9).

3. Jussiaea suffruticsa L. (berbentuk herba tegak berasal dari ekosistem sawah di Desa Tulo Kecamatan Dolo, pada ketinggian $41 \mathrm{~m} \mathrm{dpl}$ dengan $\mathrm{pH}$ tanah 7.2).

4. Bidens pilosa L. var. minor (Blume) Sckerff (berbentuk herba semusim berasal dari ekosistem kebun di Desa Tulo Kecamatan Dolo, pada ketinggian $41 \mathrm{~m}$ dpl dengan $\mathrm{pH}$ tanah 7.2).

5. Euphorbia prunifolia Jacq (berbentuk herba semusim berasal dari ekosistem kebun di Desa Sidondo Kecamatan Gumbasa, pada ketinggian $56 \mathrm{~m}$ dpl dengan $\mathrm{pH}$ tanah 7.0).

6. Oplismenus sompositus (L.) Beauv. (berbentuk rumput menjalar berasal dari ekosistem padang rumput di Desa Sidondo Kecamatan Gumbasa, pada ketinggian 56 m dpl dengan $\mathrm{pH}$ tanah 73). 


\section{Jurnal agrotech 8 (1) 8-17}

7. Ipomoa quamoclit L. (berbentuk memanjat semusim berasal dari ekosistem kebun di Desa Sidondo Kecamatan Gumbasa, pada ketinggian $62 \mathrm{~m}$ dpl dengan $\mathrm{pH}$ tanah 7.1).

8. Digitaria agrotistachya (Steud.) Fern. (berupa rumput-rumputan berasal dari ekosistem sawah di Desa Sidondo Kecamatan Gumbasa, pada ketinggian $62 \mathrm{~m}$ dpl dengan $\mathrm{pH}$ tanah 7.0).

9. Hyptis capitata Jacq. (tergolong herba menahun berasal dari ekosistem sawah di Desa Pandere Kecamatan Gumbasa, pada ketinggian $90 \mathrm{~m}$ dpl dengan $\mathrm{pH}$ tanah 7.0).

10. Scindapsus pictus Hassk. (termasuk memanjat dan menempel pada pohon berasal dari ekosistem kebun di Desa Pandere Kecamatan Gumbasa, pada ketinggian $90 \mathrm{~m}$ dpl dengan $\mathrm{pH}$ tanah 7.0)

11. Ruellia tuberosa L. (berbentuk herba semusim berasal dari ekosistem kebun di Desa Pandere Kecamatan Gumbasa, pada ketinggian $104 \mathrm{~m} \mathrm{dpl} \mathrm{dengan} \mathrm{pH}$ tanah 6.9).

12. Brachiaria mutica (Forsk.) Stapf. (berbentuk herba menahun berasal dari ekosistem kebun di Desa Omu Kecamatan Gumbasa, pada ketinggian $153 \mathrm{~m}$ dpl dengan $\mathrm{pH}$ tanah 6.9).

13. Sphaerostephanos sarasinorum Holttum. (berbentuk paku herba tegak berasal dari ekosistem sawah di Desa Omu Kecamatan Gumbasa, pada ketinggian $153 \mathrm{~m} \mathrm{dpl}$ dengan $\mathrm{pH}$ tanah 6.6).

14. Physalis angulata L. (berbentuk herba semusim berasal dari ekosistem kebun di Desa Omu Kecamatan Gumbasa, pada ketinggian $162 \mathrm{~m}$ dpl dengan $\mathrm{pH}$ tanah 6.4).

15. Echinochloa crus-galli (L.) Beauv. (termasuk rumput-rumputan berasal dari ekosistem kebun di Desa Salua Kecamatan Kulawi, pada ketinggian $348 \mathrm{~m}$ dpl dengan $\mathrm{pH}$ tanah 6.5).

16. Curculigo latifolia $\mathrm{L}$. (berbentuk terna tegak $0,40-1 \mathrm{~m}$ berasal dari ekosistem kebun di Desa Salua Kecamatan Kulawi, pada ketinggian $346 \mathrm{~m}$ dpl dengan $\mathrm{pH}$ tanah 6.3).

17. Gleichenia linearis (Burm.f.) Clarce. (merupakan paku merambat berasal dari ekosistem hutan di Desa Bolapapu Kecamatan Kulawi, pada ketinggian 750 m dpl dengan $\mathrm{pH}$ tanah 5.8).

18. Mimosa invisa Mart. (termasuk merambat semusim, berupa terna berasal dari ekosistem kebun di Desa Bolapapu
e-ISSN : 2621-7236

p-ISSN : 1858-134X

Kecamatan Kulawi, pada ketinggian $750 \mathrm{~m}$ dpl dengan $\mathrm{pH}$ tanah 5.1).

19. Euphorbia hirta L. (berupa terna tegak dan memanjat berasal dari ekosistem kebun, di Desa Bolapapu Kecamatan Kulawi, pada ketinggian $734 \mathrm{~m}$ dpl dengan $\mathrm{pH}$ tanah 6.7).

20. Calopogonium mucunoides Desv. (berbentuk terna merayap membelit ke kiri berasal dari ekosistem kebun di Desa Lawua Kecamatan Kulawi Selatan, pada ketinggian $429 \mathrm{~m}$ dpl dengan $\mathrm{pH}$ tanah 6.5).

21. Momordica cochinchinensis (Lour.) Spreng. (termasuk merambat berasal dari ekosistem kebun di Desa Lawua Kecamatan Kulawi Selatan, pada ketinggian $430 \mathrm{~m}$ dpl dengan $\mathrm{pH}$ tanah 6.6).

22. Senna siamea (Lam.) Irwin \& Barneby. (berbentuk perdu berasal dari ekosistem hutan di Desa Tomua Kecamatan Kulawi Selatan, pada ketinggian $392 \mathrm{~m}$ dpl dengan $\mathrm{pH}$ tanah 5.8).

23. Melanolepis multiglandulosus (Blume) Rchb.F. \& Zoll. (berbentuk perdu berasal dari ekosistem hutan di Desa Tomua Kecamatan Kulawi Selatan, pada ketinggian $458 \mathrm{~m}$ dpl dengan $\mathrm{pH}$ tanah 5.7).

24. Sida rhombifolia L. (berbentuk perdu kecil atau herba tegak berasal dari ekosistem kebun di Desa Tomua Kecamatan Kulawi Selatan, pada ketinggian $458 \mathrm{~m}$ dpl dengan $\mathrm{pH}$ tanah 5.8).

25. Jatropha gossypifolia L. (berbentuk perdu atau pohon kecil berasal dari ekosistem padang rumput di Desa Watunonju Kecamatan Biromaru, pada ketinggian 133 $\mathrm{m}$ dpl dengan $\mathrm{pH}$ tanah 6.6).

26. Breynia microphylla (Kurz ex T 7 B) M.A. (berbentuk perdu berasal dari ekosistem padang rumput di Desa Watunonju Kecamatan Biromaru, pada ketinggian 136 $\mathrm{m}$ dpl dengan $\mathrm{pH}$ tanah 6.7).

27. Eleusina indica Gaerth. (berupa rumput semusim berasal dari ekosistem kebun di Desa Sigimpu Kecamatan Biromaru, pada ketinggian $576 \mathrm{~m}$ dpl dengan $\mathrm{pH}$ tanah 6.5).

28. Cyperus tenuispica Steud. (berupa herba menahun atau semusim berasal dari ekosistem sawah di Desa Berdikari Kecamatan Palolo, pada ketinggian $616 \mathrm{~m}$ dpl dengan $\mathrm{pH}$ tanah 6.3).

29. Scoparia dulcis L. (berupa herba tegak berasal dari ekosistem sawah di Desa Tongoa Kecamatan Kamarora, pada ketinggian $646 \mathrm{~m} \mathrm{dpl} \mathrm{dengan} \mathrm{pH}$ tanah 6.3). 


\section{Jurnal Agrotech 8 (1) 8-17}

30. Cyathula prostrate Blume. (berupa terna tahunan berasal dari ekosistem sawah di Desa Tongoa Kecamatan Kamarora, pada ketinggian $646 \mathrm{~m}$ dpl dengan $\mathrm{pH}$ tanah 6.1).

Vegetasi tingkat pancang :

1. Leucaena leucocephala (Lam.) de Wit. (berbentuk pohon kecil berasal dari ekosistem hutan di Desa Pandere Kecamatan Gumbasa, pada ketinggian $104 \mathrm{~m}$ dpl dengan pH tanah 6.9).

2. Piper aduncum L. (termasuk perdu atau pohon kecil berasal dari ekosistem hutan di Desa Salua Kecamatan Kulawi, pada ketinggian $348 \mathrm{~m}$ dpl dengan $\mathrm{pH}$ tanah 6.5).

3. Villebrunea rubescens Blume. (berbentuk perdu atau pohon berasal dari ekosistem hutan di Desa Salua Kecamatan Kulawi, pada ketinggian $346 \mathrm{~m}$ dpl dengan $\mathrm{pH}$ tanah 6.6).

4. Leucosyke capitellata Wedd. (berbentuk perdu atau pohon berasaldari ekosistem kebun di Desa Namo Kecamatan Kulawi, pada ketinggian $639 \mathrm{~m}$ dpl, $\mathrm{pH}$ tanah 6.9).

5. Neonauclea ventricosa Ridsd. (berbentuk perdu atau pohon kecil hingga besar berasal dari ekosistem hutan di Desa Poleroa Kecamatan Kulawi, pada ketinggian $623 \mathrm{~m}$ dpl dengan $\mathrm{pH}$ tanah 7.0).

6. Calotropis gigantea R.Br. (berbentuk perdu tegak hingga $3 \mathrm{~m}$ berasal dari ekosistem padang rumput di Desa Watunonju Kecamatan Biromaru, pada ketinggian 136 $\mathrm{m}$ dpl dengan $\mathrm{pH}$ tanah 6.8).

7. Crotalaria anagyroides H.B.K.(berbentuk perdu berasal dari ekosistem kebun di Desa Sigimpu Kecamatan Biromaru, pada ketinggian $569 \mathrm{~m}$ dpl dengan $\mathrm{pH}$ tanah 6.5).

8. Stachytarpheta jamaicensis (L.) Vahl. (berbentuk perdu pendek berasal dari ekosistem kebun di Desa Petimbe Kecamatan Biromaru, pada ketinggian $594 \mathrm{~m}$ dpl dengan pH tanah 6.6).

9. Ischaemum rugosum Salisb. (berupa herba menahun atau semusim berasal dari ekosistem sawah di Desa Berdikari Kecamatan Palolo, letak pada ketinggian 618 $\mathrm{m}$ dpl dengan $\mathrm{pH}$ tanah 6.5).

10. Cuphea balsamona Cham. \& Schlecht. (berupa perdu kecil berasal dari ekosistem kebun di Desa Tongoa Kecamatan Kamarora, letak pada ketinggian $645 \mathrm{~m} \mathrm{dpl}$ dengan $\mathrm{pH}$ tanah 5.5).

11. Eupatorium odoratum L.(berupa perdu atau herba besar berasal dari ekosistem kebun di Desa Tongoa Kecamatan Kamarora, pada ketinggian $646 \mathrm{~m}$ dpl dengan $\mathrm{pH}$ tanah 6.1).
e-ISSN : 2621-7236

p-ISSN : 1858-134X

12. Crassocephalum crepidioides (Benth.) S. Moore. (berupa herba berasal dari ekosistem kebun di Desa Lembang Tongoa Kecamatan Kamarora, pada ketinggian $1.055 \mathrm{~m} \mathrm{dpl}$ dengan $\mathrm{pH}$ tanah 5.9).

Vegetasi tingkat tiang :

1. Canarium vulgare Leench. (berbentuk pohon besar, tinggi $45 \mathrm{~m}$, berbanir berasal dari ekosistem hutan di Desa Namo Kecamatan Kulawi, pada ketinggian $607 \mathrm{~m}$ dpl dengan $\mathrm{pH}$ tanah 6.6).

2. Pterospermum celebicum Miq. (berbentuk pohon ukuran sedang dengan tinggi hingga $25 \mathrm{~m}$ berasal dari ekosistem hutan di Desa Poleroa Kecamatan Kulawi, pada ketinggian $633 \mathrm{~m}$ dpl dengan $\mathrm{pH}$ tanah 6.8).

3. Schizostachyum brachycladum Kurz. (berrumpun, tegak hingga $15 \mathrm{~m}$ berasal dari ekosistem hutan di Desa Petimbe Kecamatan Biromaru, pada ketinggian $569 \mathrm{~m}$ dpl dengan $\mathrm{pH}$ tanah 6.5).

4. Erythrina subumbrans Merr. (berupa pohon, tinggi hingga $22 \mathrm{~m}$ berasal dari ekosistem hutan di Desa Lembang Tongoa Kecamatan Kamarora, pada ketinggian $1075 \mathrm{~m}$ dpl dengan $\mathrm{pH}$ tanah 6.4).

5. Ficus minahassae (Teijsm \& de Vriese) Miq. (berupa pohon kecil, tinggi hingga $25 \mathrm{~m}$ berasal dari ekosistem hutan di Desa Lembang Tongoa Kecamatan Kamarora, pada ketinggian $1223 \mathrm{~m}$ dpl dengan $\mathrm{pH}$ tanah 6.7).

6. Elmerrillia ovalis Miq. Dandy. (berupa pohon besar, tinggi hingga $45 \mathrm{~m}$ berasal dari ekosistem hutan di Desa Lembang Tongoa Kecamatan Kamarora, pada ketinggian 1235 $\mathrm{m}$ dpl dengan $\mathrm{pH}$ tanah 5.4).

Kultivasi mikrob dari sampel

Kultivasi mikrob dari sampel daun dan tanah, diperoleh 144 konsorsium mikrob filosfer dan 48 konsorsium mikrob rizosfer. Kultivasi konsorsium mikrob pada media cair dan padat disajikan pada Gambar 2.

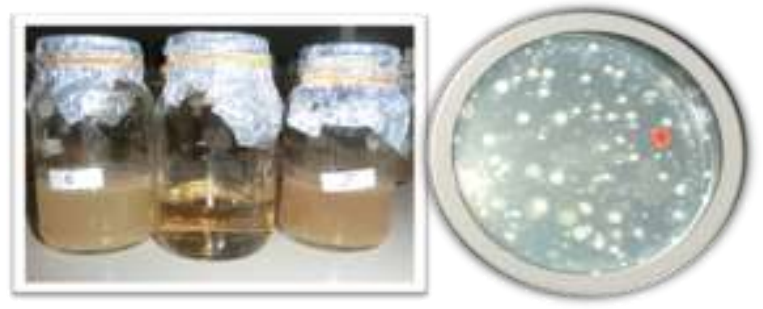

Gambar 2. Konsorsium mikrob pada media cair dan padat $\quad \mathrm{a}=$ Mikrob filosfer dan mikrob rizosfer pada media cair, $b=$ Mikrob filosfer pada media nutrien agar (NA) 


\section{Jurnal Agrotech 8 (1) 8-17}

Nama dan kode konsorsium mikrob filosfer dan rizosfer disajikan pada Tabel 1 .

Table 1. Nama dan kode konsorsium mikrob filosfer dan rizosfer

\begin{tabular}{|c|c|c|c|}
\hline \multirow[t]{2}{*}{ No } & \multirow[t]{2}{*}{ Nama tumbuhan asal } & Kode & konsorsium \\
\hline & & Filosfer & Rizosfer \\
\hline 1 & Lantana camara $\mathrm{L}$. & Fm1, Fs1, Ft1 & R1 \\
\hline 2 & Ageratum conyzoides L. & $\mathrm{Fm} 2, \mathrm{Fs} 2, \mathrm{Ft} 2$ & $\mathrm{R} 2$ \\
\hline 3 & Jussiaea suffruticsa L. & $\mathrm{Fm} 3, \mathrm{Fs} 3, \mathrm{Ft} 3$ & R3 \\
\hline 4 & Bidens pilosa $\mathrm{L}$. & Fm4, Fs4, Ft4 & $\mathrm{R} 4$ \\
\hline 5 & E. prunifolia Jacq & Fm5, Fs5, Ft5 & R5 \\
\hline 6 & O. sompositus Beauv. & Fm6, Fs6, Ft6 & R6 \\
\hline 7 & Ipomoa quamoclit $\mathrm{L}$. & Fm7, Fs7, Ft7 & $\mathrm{R} 7$ \\
\hline 8 & D. grotistachya Steud. & Fm8, Fs8, Ft8 & $\mathrm{R} 8$ \\
\hline 9 & Hyptis capitata Jacq. & Fm9, Fs9, Ft9 & R9 \\
\hline 10 & S. pictus Hassk. & Fm10, Fs10, Ft10 & $\mathrm{R} 10$ \\
\hline 11 & L. leucocephala Lam. & Fm11, Fs 11, Ft11 & $\mathrm{R} 11$ \\
\hline 12 & Ruellia tuberosa L. & Fm12, Fs 12, Ft12 & $\mathrm{R} 12$ \\
\hline 13 & B. mutica Forsk. & Fm13, Fs13, Ft13 & $\mathrm{R} 13$ \\
\hline 14 & S. sarasinorum L. & Fm14, Fs14, Ft14 & $\mathrm{R} 14$ \\
\hline 15 & Physalis angulata $\mathrm{L}$. & Fm 15, Fs 15, Ft 15 & $\mathrm{R} 15$ \\
\hline 16 & E. crus-galli L. & Fm16, Fs 16, Ft16 & $\mathrm{R} 16$ \\
\hline 17 & Piper aduncum L. & Fm17, Fs17, Ft17 & $\mathrm{R} 17$ \\
\hline 18 & Curculigo latifolia $\mathrm{L}$. & Fm 18, Fs 18, Ft 18 & $\mathrm{R} 18$ \\
\hline 19 & V. rubescens Blume. & Fm19, Fs19, Ft19 & $\mathrm{R} 19$ \\
\hline 20 & C.vulgare Leeench. & $\mathrm{Fm} 20, \mathrm{Fs} 20, \mathrm{Ft} 20$ & $\mathrm{R} 20$ \\
\hline 21 & L. capitellata Wedd. & Fm21, Fs21, Ft21 & $\mathrm{R} 21$ \\
\hline 22 & G. linearis Burm.f. & $\mathrm{Fm} 22, \mathrm{Fs} 22, \mathrm{Ft} 22$ & $\mathrm{R} 22$ \\
\hline 23 & Mimosa invisa Mart. & $\mathrm{Fm} 23, \mathrm{Fs} 23, \mathrm{Ft} 23$ & $\mathrm{R} 23$ \\
\hline 24 & Euphorbia hirta L. & $\mathrm{Fm} 24, \mathrm{Fs} 24, \mathrm{Ft} 24$ & $\mathrm{R} 24$ \\
\hline 25 & P. celebicum Miq. & $\mathrm{Fm} 25, \mathrm{Fs} 25, \mathrm{Ft} 25$ & $\mathrm{R} 25$ \\
\hline 26 & N. ventricosa Ridsd. & Fm26, Fs 26, Ft26 & $\mathrm{R} 26$ \\
\hline 27 & C. mucunoides Desv. & $\mathrm{Fm} 27, \mathrm{Fs} 27, \mathrm{Ft} 27$ & $\mathrm{R} 27$ \\
\hline 28 & M.cochinchinensis Lour. & $\mathrm{Fm} 28, \mathrm{Fs} 28, \mathrm{Ft} 28$ & $\mathrm{R} 28$ \\
\hline 29 & Senna siamea Lam. & Fm29, Fs29, Ft29 & $\mathrm{R} 29$ \\
\hline 30 & M. multiglandulosus L. & $\mathrm{Fm} 30, \mathrm{Fs} 30, \mathrm{Ft} 30$ & R30 \\
\hline 31 & Sida rhombifolia $\mathrm{L}$. & Fm31, Fs31, Ft31 & R31 \\
\hline 32 & J. gossypifolia L. & Fm32, Fs32, Ft32 & R32 \\
\hline 33 & C. gigantea $\mathrm{R} . \mathrm{Br}$. & Fm 33, Fs 33, Ft33 & R33 \\
\hline 34 & B. microphylla Kurz & Fm34, Fs34, Ft34 & R34 \\
\hline 35 & Eleusina indica Gaerth. & $\mathrm{Fm} 35, \mathrm{Fs} 35, \mathrm{Ft} 35$ & R35 \\
\hline 36 & C. anagyroides H.B.K. & Fm36, Fs36, Ft36 & R36 \\
\hline 37 & S. brachycladumL. & Fm37, Fs37, Ft37 & R37 \\
\hline 38 & S. jamaicensis L. & $\mathrm{Fm} 38, \mathrm{Fs} 38, \mathrm{Ft} 38$ & R38 \\
\hline 39 & I. rugosum Salisb. & Fm39, Fs39, Ft39 & R39 \\
\hline 40 & C. tenuispica Steud. & Fm40, Fs40, Ft40 & $\mathrm{R} 40$ \\
\hline 41 & Cuphea balsam L. & Fm41, Fs41, Ft41 & $\mathrm{R} 41$ \\
\hline 42 & Scoparia dulcis $\mathrm{L}$. & Fm42, Fs42, Ft42 & $\mathrm{R} 42$ \\
\hline 43 & E. odoratum L. & Fm43, Fs43, Ft43 & $\mathrm{R} 43$ \\
\hline 44 & C. prostrate Blume. & Fm44, Fs44, Ft44 & $\mathrm{R} 44$ \\
\hline 45 & E. subumbrans Merr. & Fm45, Fs45, Ft45 & $\mathrm{R} 45$ \\
\hline 46 & C. crepidioides L. & Fm46, Fs46, Ft46 & $\mathrm{R} 46$ \\
\hline 47 & Ficus minahassae L. & Fm47, Fs47, Ft47 & R47 \\
\hline 48 & E. ovalis Miq. Dandy. & Fm48, Fs 48, Ft48 & $\mathrm{R} 48$ \\
\hline
\end{tabular}

\section{Pembahasan}

Hasil eksplorasi pada ekosistem di Kabupaten Sigi menunjukkan bahwa berpotensi diperoleh mikrob dalam bentuk konsorsium. Hal ini dibuktikan melalui kultivasi mikrob dari sampel yang diperoleh.Hasil kultivasi mikrob menunjukkan bahwa sampel mengandung konsorsium mikrob filosfer dan mikrob rizosfer, karena terjadinya kekeruhan dan terbentuknya gas pada media cair serta dibuktikan dengan
e-ISSN : 2621-7236

p-ISSN : 1858-134X

terbentuknya koloni mikrob pada media padat nutrien agar (NA). Adanya kekeruhan larutan dan terbentuknya gas merupakan akibat respirasi mikrob yang terjadi. Sejalan dengan pendapat Saraswati et al. (2007), bahwa pertumbuhan mikrob ditandai dengan terjadinya kekeruhan dan gas pada media cair dan terbentuknya koloni mikrob pada media padat.

Azevado et al. (2000) menyatakan, mikrob daun hidup pada dua habitat pada daun, yaitu sebagai epifit dan endofit. Mikrob epifit adalah mikrob yang hidup pada sekitar permukaan daun, yang umumnya didominasi oleh bakteri dan populasinya bervariasi antara $10^{2}$ hingga $10^{6}$ sel $\mathrm{cm}^{-2}$ luas daun (Lindow \& Brandl 2003; Morris et al. 1996). Bakteri tersebut terdapat pada trikoma, stomata, sepanjang tulang daun, dinding sel epidermis (Mariano \& Carter 1993) dan spora atau miselium fungi (Kinkel 1997), serta jaringan intraseluler vaskuler (Hallman 2001). Jenis bakteri yang paling sering ditemui di daun adalah pseudomonas, xanthomonas, flavobacterium, archromobacter, bacillus, mycobacterium, beijerinckia, azotobacter dan mycoplana (Werner\& Newton 2005). Wellner et al. (2011) menambahkan, bakteri Methylobacterium adalah salah satu jenis bakteri yang hidup berasosiasi dengan tanaman. Bakteri ini mempengaruhi proses metabolisme tanaman dan meningkatkan hasil tanaman.

Banyak faktor yang memberikan kontribusi untuk membentuk komunitas mikrob yang berbeda dalam suatu ekosistem, termasuk isyarat lingkungan seperti seperti suhu dan ketersediaan air, interaksi antar mikrob, genotip dan fenotip tanaman. Kondisi ekosistem Kabupaten Sigi mendukung diperolehnya sumber konsorsium mikrob filosfer dan rizosfer. Dalam wilayah Kabupaten Sigi, juga terdapat kawasan Taman Nasional Lore Lindu (TNLL) dengan luas 229177.5 ha berdasarkan SK No. 593/Kept.II/93, tanggal 10 Mei 1993. Sebagai salah satu kawasan konservasi di Indonesia, TNLL memiliki banyak predikat atau status, karena potensi dan keunikan yang dimilikinya, di antaranya adalah sebagai cagar biosfer oleh MAB-UNESCO, World Heritage Site oleh UNESCO, kawasan burung endemik oleh Endemic Bird Area (EBA), pusat keanekaragaman tumbuhan oleh Center of Plant Diversity (CPD) dan wilayah ekologi global 200 oleh Global 200 Ecoregion-G200 ES. Kawasan ini memiliki jenis luar biasa dari ekosistem teresterial dan kelautan dunia, seperti kekayaan spesies, endemisitas spesies, keunikan taksonomi 


\section{Jurnal Oarotech 8 (1) 8-17}

yang tinggi, fenomena ekologi dan evolusi serta habitat utama (BBTNLL 2009).

Ramadanil (2009) menyatakan bahwa Sulawesi memiliki keanekaragaman hayati dengan tingkat endemisitas yang tinggi. Diperkirakan $15 \%$ dari tumbuhan berbunga di Sulawesi adalah endemik (Whitten et al. 1987). van Balgooy et al. (1996) melaporkan 933 tumbuhan asli dari Sulawesi di mana 112 di antaranya adalah endemik Sulawesi. Endemisitas tumbuhan berbunga di Sulawesi sangat bervariasi menurut taksonnya. Didukung oleh Rao (1995), pada tahun 1956, Ruineir telah mengembangkan konsep filosfer di pohon-pohon dalam hutan tropis di Indonesia.Sesuai pendapat Reisberget al. (2013), faktor lingkungan seperti iradiasi sinar matahari, musim, letak geografis dan lokasi pengambilan sampel diakui sebagai faktor penting dalam membentuk mikrobiota filosfer.

Jumlah kekayaan spesies, marga dan famili untuk vegetasi tingkat pancang, tiang dan bawah berbeda-beda pada setiap ekosistem. Keragaman mikrob dapat pula dilihat dari berbagai habitat. Setiap habitat yang berbeda memberikan keragaman yang berbeda pula. Mikrob tidak dapat dipisahkan dengan lingkungan biotik dan abiotik dari suatu ekosistem, karena berperan sebagai pengurai. Sebagaimana dijelaskan oleh Rao (1982), mikrob yang berada di dalam tanah berperan penting dalam proses pembusukan, humifikasi dan mineralisasi.

Komposisi kuantitatif populasi dalam tanah sangat tergantung pada sumber dan kondisi alami dari tanah serta kondisi relatif dari unsur organik dan anorganik. Keadaan iklim daerah dan keragaman tanaman yang tumbuh juga menentukan berlimpahnya mikrob yang mendiami tanah tersebut. Faktor yang berpengaruh terhadap komposisi relatif populasi mikrob, di antaranya adalah reaksi yang berlangsung dalam tanah, kadar kelembaban dan kondisi aerasi tanah (Sutedjo et al. 1996). Widyati (2013) menyatakan kolonisasi tegakan tanaman secara alami dikendalikan oleh struktur komposisi mikrob di rizosfer. Distribusi suatu jenis tanaman dalam suatu hamparan ditentukan oleh kehadiran atau ketidakhadiran suatu mikrob simbion yang diperlukan pada rizosfernya.

Kolonisasi rhizobia endofit dalam tanaman dapat meningkatkan pertumbuhan dan hasil gabah padi, gandum, jagung dan barley. Selain penambatan biologi, kehadiran rhizobia dalam akar memiliki banyak manfaat lain, yaitu produksi hormon tanaman seperti IAA dan GA. Hormon ini memacu perluasan permukaan dan
e-ISSN : 2621-7236

p-ISSN : 1858-134X

arsitektur akar, sehingga meningkatkan kekuatan tumbuh bibit padi, efisiensi penyerapan fosfat, pelarutan fosfat, meningkatkan efisiensi fotosintesis dan respirasi akar, meningkatkan ketahanan terhadap cekaman lingkungan dan serangan patogen (Chi et al. 2010).

Mikrob yang menghuni daun yang pada mulanya diragukan keberadaanya, kini para peneliti telah meyakini bahwa mikrob filosfer berimplikasi nyata terhadap peningkatan produksi tanaman (Pati 1992; Egamberdieva 2008). Setiap jenis tumbuhan dapat mendukung populasi mikrob, baik keragaman maupun kuantitasnya melalui residu yang dihasilkan. Akibatnya terjadi saling ketergantungan antara mikrob dengan inangnya (Gofar 2003). Hasil eksplorasi potensi mikrob yang hidup di daerah perakaran, sejak lama diketahui bahwa banyak mikrob potensial dan sangat prospek untuk dimanipulasi, termasuk yang berperan dalam pelarutan fosfat (Burns 1989; Tarafdar \& Jungk 1987).

Daun merupakan salah satu habitat mikrob saprofit (filosfer) dan populasi mikrob yang menghuni permukaan daun disebut filoplen. Mikrob yang mendiami permukaan daun sangat bervariasi sesuai dengan jenis tumbuhannya. Setiap tumbuhan mempunyai daun yang berbeda, baik dari segi bentuk, ukuran maupun eksudat yang dikeluarkannya. Perbedaan tersebut menyebabkan mikrob yang menghuninya juga berbeda, walaupun pada tumbuhan tertentu ditemukan populasi mikrob yang sama (Ismaeel et al. 2012). Demikian pula daerah perakaran tumbuhan merupakan daerah yang sangat dinamis bagi berbagai jenis mikrob tanah terutama mikrob yang terlibat dalam pertumbuhan tanaman. Hal ini terutama dipengaruhi oleh melimpahnya senyawa organik yang dieksudasi oleh akar yang dapat dijadikan sebagai nutrisi bagi mikrob yang hidup di rizosfer (Burns 1989; Tarafdar dan Jungk 1987).

\section{Kesimpulan}

Kabupaten Sigi memiliki keanekaragaman hayati pada berbagai ekosistem berupa sawah, kebun padang rumput dan hutan. Diperoleh sampel sebanyak 48 jenis tumbuhan berasal dari berbagai ekosistem berupa sawah, kebun, padang rumput dan hutan. Hasil eksplorasi berdasarkan tingkat tumbuhan diperoleh : tumbuhan tingkat bawah 30 jenis, tingkat tiang 12 jenis dan tingkat pancang 6 jenis. 


\section{Jurnal Agrotech 8 (1) 8-17}

Hasil kultivasi mikrob diperoleh 144 konsorsium mikrob filosfer dan 48 konsorsium mikrob rizosfer. Konsorsium yang diperoleh kemudian diuji efektivitasnya terhadap pertumbuhan dan hasil tanaman padi pada tahap penelitian selanjutnya.

\section{Ucapan Terima Kasih}

Ucapan terima kasih disampaikan kepada Dirjend Dikti yang telah memberikan beasiswa BPPS tahun 2010 - 2014 dan Pemda Sulawesi Tengah yang telah memberikan biaya penelitian tahun 2012.

\section{Daftar Pustaka}

Azevado JL, Maccheroni WJr. Pereira JO. 2000. Endophytic microorganism : A review on insect control and recent advances on tropical plants. EJB 3:40-65.Doi 10.2225/vol3-issue1-fulltext-4.

[BBTNLL] Balai Besar Taman Nasional Lore Lindu 2009. Inventarisasi Potensi Taman Nasional Lore Lindu Sulawesi Tengah Bekerjasama dengan Herbarium Celeben (CEB) Palu Sulawesi Tengah (IN): Universitas Tadulako

[BPS] Badan Pusat Statistik 2010. Sulawesi Tengah dalam Angka 2009. Badan Pusat Statistik. Palu, Sulawesi Tengah.

Bills GF. 1996. Isolation and analysis of endophytic fungal communities from woody plants. P. 31 - 65. Redlin S, Carries LM (Ed). Sistematic, ecology, and evolution of endophytic fungi in grasses and woody plants. APS Press, St Paul, $\mathrm{MN}$. (in press).

Burns 1989. Cyanogenic microbes and phosphatase enzymes in the rhizosphere: Properties and Prospects for Manipulation. Developments in Soil Science 18: 191-199.

Chi F, Yang P, Han F, Jing Y, Shen S. 2010. Proteomic analysis of rice seedlings infected by sinorhizobium meliloti 1021. Proteomics 10 : 1861 - 1874 .

Egamberdieva D, 2008. Plant growth promoting properties of rhizobacteria isolated from wheat and pea grown in loamy sand soil. Department of Biotechnology and Microbiology, National University of
e-ISSN : 2621-7236

p-ISSN : 1858-134X

Uzbekistan, Vuzgorodok, 100174 Tashkent, Uzbekistan. Turk J Biol 32 (2008) 9-15

Fachrul MF. 2007. Metode Sampling Bioteknologi. Jakarta (IN) : Bumi Aksara.

Freiberg E. 1998. Microclimatic parameters influencing nitrogen fixation in the phylosphere in a Costa Rican premontane rain forest. Abstract $117: 9-18$. Issue 1/2.

Gofar N. 2003. Eksplorasi konsorsium Mikrob daun asal tumbuhan dari ekosistem air hitam Kalimantan Tengah dan aplikasinya sebagai pemacu pertumbuhan tanaman jagung pada ultisol [Disertasi]. Bandung (IN): Program Pascasarjana Universitas Padjadjaran.

Hallman J. 2001. Plant interaction with endophytic bacteria. Germany (GR): Institut fot Plant Diseases. University of Bonn, Nubalee 9,53115 Bonn.

Ismaeel NA, Finkel OM, Glaser F, Sharon I, Schneider R, Post AF, Spudich JL, Mering vC. Vorholt JA, Iluz D, Beja O, Belkin S. 2012. Microbial rhodopsins on leaf surface of terrestrial plants. Enviromental Microbiology 14 91) : 140146.

Kinkel LL. 1997. Microbial population dynamic on leaves. Annu Rev. Phytopathology. 35 ; $327-347$.

Lindow SE, Brandl MT. 2003. Microbiology of phyllosphere. Appl.Environ.Microbiol. 69:1875-1883.Doi 10.1128/AEM.69.4.1875-1883.2003.

Mariano RLR, McCarter SM. 1993. Epiphytic survival of Pseudomonasviridiflava on tomato and selected weed species. Microbiol Ecology. 26:47-58.Doi 10.1007/BF00166029.

Morris CE, Nicot PC, Nguyen C. 1996. Aerial plant surface microbilogy. The languange of science. 307p. Doi 10.1007/b102414.

Morris CE. 2001. Phyllosphere. Encyclopedia of Life Sciences. 1-8.

Pati BR. 1992. Effect of spraying nitrogen fixing phyllospheric bacterial isolates on rice plants. Zentralbl Mikrobiol147:441-446. Doi10.1016/S0232-4393(11)80312-4.

Ramadanil 2009. Keanekaragaman Hayati Tumbuhan Sulawesi, Potensi dan Tantangan Taksonomi Tumbuhan. Pidato 
Jurnal $\boldsymbol{O}_{\text {grotech }} 8$ (1) 8-17

Pengukuhan Guru Besar dalam Bidang Taksonomi Tumbuhan Universitas tadulako. Palu, 15 Agustus 2009.

Rao NSS. 1982. Biofertilizer in Agriculture.London (GB): Oxford \& IBH. Pub. Co. 186p.

Rao NSS. 1995. Soil microorganism and plant growth. $3^{\text {rd }}$. Edition. New Hampshire (US):Science Publishers, Inc. 335p.

Reisberg EE, Hildebrandt U, Riederer M, Hentschel U. 2013. Distinct phyllosphere bacterial communities on Arabidopsis wax mutant leaves. PLoS ONE 8(11): e78613. doi:10.1371/journal.pone.0078613

Saraswati R, Husen E, Simanungkalit RDM. 2007. Metode Analisis Biologi Tanah. Jakarta (ID): Balai Besar Litbang Sumberdaya Pertanian. Badan Penelitian dan Pengembangan Pertanian. Departemen Pertanian. 270p

Steel RGD, Torrie JH. 1980. Principle and Procedures of Statistic.

Biometrical Approach. $2^{\text {nd }}$ Ed. McGrawHill, New York, NY.

Sturz AV., Nowak J. 2000. Endophytic communities of rhizobacteria and strategis required to create yield-enhancing association with crops. Appl. Soil Ecol. 15 : $183-190$.

Sutedjo MM, AG. Kartasapoetra, RD.S. Sastroatmodjo. 1996. Mikrobiologi Tanah. Jakarta (ID): Rineka Cipta.

Suto M. 2001. Isolation of endophytes from plants. Lab of Applied Microbilogy. Faculty of Agric.Japan (JP): Hokaido University.
e-ISSN : 2621-7236

p-ISSN : 1858-134X

Tarafdar \& Jungk 1987. Phosphatase activity of rhizosphere soil and and its relation to the depletion of soil organic phosphorus. Soil Biol Biochem 3:199.

van Balgooy MMJ, Hovenkamp PH, Welzen PC. 1996. Phytogeography of the pasific floristic and historical distribution pattern in plant. In the origin and evolution of pasific island biotas. New Gunea to Eastern Polynesia; pattern and process. Pp 191 - 213. Edited by Keast A, Miller SA, SPB Academic Publishing bv. Amsterdam.

Wellner S, N Lodders, P Kampfer. 2011. Diversity and biogeography of selected phyllosphere bacteria wit special emphasis on Methylobacterium spp. Systematic and Applied Microbiology. 34:621630.Doi10.1016/j.syapm.2011.08.005.

Werner D, Newton WE. 2005. Nitrogen fixation in agriculture, forestry, ecology, and the environment.Dordrecht, The Netherlands (ND): Springer, P.O. Box 17, 3300 AA. $347 p$.

Whitten AJ., M. Mustafa and GS. Henderson. 1987. The Ecology of Sulawesi. Yogyakarta (IN): Gadjah Mada University Press.

Widyati E. 2013. Dinamika komunitas mikroba di rizosfer dan konstribusinya terhadap pertumbuhan tanaman hutan. Tekno Hutan Tanaman 6(2): 56-64. 